\title{
A Multitemporal Analysis of the Master Plan of Sobral - Ceará
}

\author{
Wellington Galvão Alves ${ }^{1}$ \\ Virginia Célia Cavalcante de Holanda ${ }^{2}$
}

\begin{abstract}
The urban planning of the city of Sobral is currently guided by the participatory master plan, which had the last review in 2008, whose purpose, together with other plans, guidelines and public policies for the city, is to meet the real needs of its residents. The challenge of the analysis is to apprehend how the socio-spatial transformations of the city of Sobral occurred, from the planning actions of the public power, at different times, its determinants in the urban territorial configuration, evidenced in the forms, contained in the architecture of the buildings, in the layout the streets, the technical objects and the expansion axes of the city, each with a pre-established function. The methodology of the study consisted of literature review, critical and attentive reading of the master plans of the municipality of Sobral, interviews with technicians from the municipal government who participated in the construction of the master plans. It is possible to infer that the standardization of the territory added to the intention of modernization of the city and the urban, were very important in the structuring and qualification of the different spaces of the city, as it expanded structuring, requalification and public assistance projects, making the city more attractive for private investments and improvement in the quality of urban life.
\end{abstract}

Keywords: Master Plan. Urban Planning. City. Sobral.

\section{Introduction}

The planning perspective for Brazilian cities began between the 1960s and 1970s, and the first master plans did not include participatory processes. The planning gained strength after the 1988 Federal Constitution, which included the articles 182 and 183 concerning Urban Policy, and the bill 181/89. This bill influenced the city statute, approved by the National Congress 12 years later, by Law 10.257 of July 10, 2001.

The 1988 Constitution, which made the elaboration of master plans to accompany the growth of cities emerge more forcefully, is a basic instrument for the implementation of urban development policy, obligatory for cities above 20,000 inhabitants. But with the Statute of the City, it extended the obligation: "[...] this requirement to cities of any size integrating metropolitan regions and urban agglomerations; or integrating areas of special tourist interest."(PINHEIRO, 2014, p. 61).

In urban planning, concepts, mechanisms, legislation, and priorities alternate due to the emergence of new problems and situations that present themselves as challenges for municipal management. The new policies are toward the increasingly social management of the urban property and the growing participation of the community in thinking about the use of the city. Planning the city is essential since this is the starting point for effective municipal management in the face of public obligations, in which the quality and efficiency will set the course for good or bad management with a direct reflection on the life of each citizen.

Our challenge is to understand how the socio-spatial transformations of the city of Sobral took place, based on the planning actions of the public power, at different times, which were determinant in the urban territorial configuration, evidenced in the forms, technical objects, and axes of expansion of the city. This temporal cutout started in 1967, in the management of mayor Jerônimo de Medeiros Prado, until the year 2020, in the mandate of mayor Ivo Ferreira Gomes.

It is important to understand the Sobral master plans and the urban development policy. The first master plan came in 1967, in the management of mayor Jerônimo de Medeiros Prado, then the second in 2000, the Plano Diretor de Desenvolvimento Urbano (urban development master plan, PDDU) in the management of mayor Cid Gomes, the third in 2008, the Plano Diretor Participativo (participative master plan, PDP) in the management of mayor Leônidas

\footnotetext{
${ }^{1}$ Specializedinmunicipal public managmentat Universidade Estadual do Ceará (Ceará State University, UECE). Master studentin thegeography graduation courseat Universidade Estadual Vale do Acaraú (Acaraú Valley State University, UVA).

${ }^{2}$ Associate professorin thegeography course UVA.
} 
Cristino, and at last the ongoing guidelines in 2020 that lead to the review. The master plan is the main planning instrument for development and urban policies.

\section{Discussing the topic, the approached area, and theoretical basis}

When talking about urban development, one implicitly understands that there is a spatial and historical construction resulting from socioeconomic activities conditioned to a production pattern, which modifies the space according to the different cultural, ideological, technical, technological, scientific, and informational rhythms of societies. The changes reveal themselves through the temporal succession and the relationships between objects and actions, which translate the different forms and functions of urban space.

According to Milton Santos (2014, p.74), the landscape is the object of change,therefore not everlasting. It is a result of successive additions and substitutions, an imprint of the history of work and techniques. These metamorphoses in space (identified by landscapes) not only present themselves as a testimony of the evolution of techniques (for each historical moment) but also as evidence of inequality between places and of socio-spatial segregation.

The city thought and planned based on the capitalist logic most of the time privileges one part of the population in detriment of the other, which is unable to access the urban land. Thus, the land is a commodity for those who can pay, leaving the poor population by themselves to acquire a piece of land. The occupation of improper areas lacking infrastructure, health, and recognized ownership, prove a model marked by socio-spatial disparities, inefficiency, and great environmental degradation (ROLNIK; KLINK, 2011, p. 90).

Critical reflection on the importance of municipal planning, which understands urban development as thought out and discussed the process along with the various participants of society in the democratic construction of spaces, makes it possible to walk against these historical inequalities. Thus, it creates new ways of including the largest number of people who can truly have a voice and representativeness in decision-making processes.

Thus, it is possible to find, from the interests of a municipal public management of democratic action, political strategies of effective participation in the construction of knowledge of the territory, meeting the experiences of the citizens. Therefore, the plan supports both the planning and political and social emancipation of the population.

Because of the importance of master plans, it is necessary to analyze and understand the role and importance of the development of Sobral. The first master plan came in 1967 under the management of the mayor Jerônimo de Medeiros Prado, whose coordinator was the engineer João José de Sá Parente. According to Alves (2011, p.173), the team consisted of a geographer, a philosopher, a doctor, a social worker, an agronomist, three engineers, two architects, and two administrators, in addition to some people from Sobral, considering its importance and application by different municipal administrations for three decades until the implementation of the second plan.

The consortium Fausto Nilo came up with the second master plan, the PDDU, in 2000, which had its studies in the management of the first mandate of Mayor Cid Gomes. A team of 16 workers in the consortium, six employees, and eight members of the municipal technical team gave birth to the PDDU (ALVES, 2011, p. 180).

In 2005, during the administration of Mayor Leônidas Cristino, the PDDU underwent a review process that aimed to extend the planning to the districts as well. The PDP had its approval in 2008 and had financial support from the Ministry of Culture in the Monumenta program because the city has its historical site tumbled (ALVES, 2011, p.191).

When analyzing the talks from society to create a review of the master plan, there are important records that prove this participation. Alves states (2011, p. 191) that a total of 11 public meetings took place in the districts and neighborhoods of Sobral, called District Forums, besides the public hearings that happened at the headquarters of the municipality. The composition of the technical team almost in its entirety (with the exception of two architects), were residents of the municipality and employees in the city hall, which brings closer the understanding of the reality, knowing as much the potential as the needs and deficiencies of the city.

\section{Introductory remarks about Sobral: from Caiçara Farm to the 1950s}

The Caiçara Farm was founded in the 18th century by Antônio Rodrigues Magalhães and his wife, Quitéria Marques de Jesus. It was part of a sesmaria whose donee was Antônio da Costa Peixoto and is historically the genesis of the current city of Sobral. The Caiçara village developed from the farm during the cattle cycle, the economic activity of the 18th century responsible for the population of the countryside of Ceará and which played an important role in the consolidation of the first urban nucleus. According to Rocha (2017), the first modeling agents of Sobral urban space were the farmers and the clergy. 
With the intervention of the State, clergy, cattle breeders and commerce, the urban integration and the conception of the orthogonal layout of the streets occurred, which in the historical process of urban expansion of the city influenced the implantation of technical objects (churches, market, squares), reflecting the interests of the high society at that time.

The socio-spatial development, resulting from the cotton cycle and the role that Sobral played in the economic, political, and social structure in the second half of the $19^{\text {th }}$ century, made it possible for its entry into the technical period $^{3}$. The construction of the railroad and the installation of the first fabric factory in 1887 were the milestones in the first industrial phase of Sobral.

The creation of the Diocese of Sobral in 1915 was a significant fact for the construction of a new political, cultural, religious, and socio-spatial scenario of the city. It marked the beginning of the work of the very first bishop, José Tupinambá da Frota. Along with his recognized entrepreneurial, administrative, and political capacity, he helped to transform the city, carrying out infrastructure works and raising buildings which today play an important socio-cultural role, in addition to the contributions to the urban configuration of the city.

When observing the spatialization of the technical objects built by the diocese, it is possible to see that the bishop not only contributed to the modernization of the urban space of Sobral but also helped to consolidate the two axes of expansion. The first axis, the hospital Santa Casa de Misericórdia, is to the West near the textile factory, and the second one, the diocesan seminary, is to the East near the CIDAO factory.

At the end of the first half of the $20^{\text {th }}$ century, one can see the importance of the legacy of the bishop at the head of the diocese of Sobral by observing the works built: The diocesan seminary (1925), the hospital Santa Casa de Misericórdia (1925), the Popular Bank of Sobral (1927), the Sant'Ana school (1934), the Chapel of St. Michael the Archangel in Sumaré (1935), the Christ the Redeemer Monument (1938), the Sobralense Gymnasium (1941), the Coração de Jesus Church (1946), the São José Professional School (1948), the Diocesan Museum - Dom José Museum (1951), the Sagrado Coração de Jesus Shelter (1953) and the Nossa Senhora de Fátima Arch (1953).

Thus, until the end of the 1950s, the urban occupation was surrounded by the train track. From the 1960s on, Sobral was the second industrial cycle of the city, based on incentives from SUDENE, which directed resources to new industries (in areas outside the train track), attracting infrastructure and contributing to urban expansion beyond the central area.

\subsection{The 1960s, Sobral second industrial cycle, and the first master plan}

The second cycle of industrialization of Sobral, influenced the process of urban expansion beyond the train tracks, on the axes North (direction Massapê), West (direction Ibiapaba), Northwest (direction Meruoca) and South (direction Fortaleza). It means that, while creating new technical objects, new demands for jobs and housing and new investments in basic infrastructure to meet the new contingents. It is at this point that the city of Sobral began to expand its urban spot effectively to the periphery, guided by the new axes of expansion.

In 1966, in the elections for mayor of Sobral, Jerônimo de Medeiros Prado emerged victoriously. In his first year as mayor, he took the initiative to request a study for the elaboration of an urban development master plan, executed by a team linked to the state government coordinated by the engineer João José de Sá Parente. About the structuring of the plan, Alves (2011, p. 175) states that its structure is 1) sector plans (education, health, and social action); 2) economic sector (agriculture, industry, credit); 3) urban sector and infrastructure (urban aspects and services, housing, water, sewage, energy, transport, and communications).

The initiative to elaborate an urban development plan was very interesting because, from it, one could have control and consequently urban planning exactly at the moment when the city started to expand beyond the tracks, which characterizes downtown. The master plan would bring the guidelines for this expansion, but unfortunately, it did not. It is not yet known the real reasons why the management of the then-mayor Jerônimo de Medeiros Prado could not effectively regulate the plan, and later, why the other managers, nor at least reviewed the study carried out for the 1967 master plan. It was only at the end of the 1990s that Sobral went through a process of study and preparation of a new master plan, that is, for three decades it remained in oblivion. In thirty years, the allotments of private initiative and real estate agents played a hegemonic role in defining the axes of expansion of the city of Sobral with the full support and incentive of the public power.

\footnotetext{
${ }^{3}$ The technical period sees the emergence of mechanized space. The objects that form the medium are not only cultural objects; they are cultural and technical at the same time (SANTOS, 2017, p. 236).
} 
In the administration of Mayor Jerônimo de Medeiros Prado, there were important construction and actions of his government that are still part of the urban structure. The milestones were the Estação de Tratamento de Água (Water Treatment Plant, ETA) of Sumaré in 1969 through an agreement with the world bank, considered at the time the most modern in Ceará, and the construction of the Plácido Aderaldo Castelo Municipal Stadium (Junco Stadium) in 1968 in the Parque Arizona allotment. It implies the modernization of the space and valorization of the mentioned allotment and contributes to the expansion axis in the Meruoca direction. In addition to Parque Arizona, the management made Sinhá Saboia and COHAB I to the South in 1970. It helped to occupy the area that had already begun with the Argentina Castelo Branco housing complex (yellow houses), close to LASSA and COSMAC, highlighting the southern expansion axis. In the northern expansion axis, its management approved the private allotment Parque Silvana II and the precarious settlement ${ }^{4}$ of Alto da Expectativa, encouraging the occupation of that portion of the urban territory out of the tracks. The occupation had already started gradually in 1961 under the management of the mayor José Palhano de Saboia.

The other urban expansion in his management was westward, towards Alto do Cristo, in 1969, with the subdivision of Parque Nossa Senhora do Perpétuo Socorro. According to Aragão (2014, p. 100), a common characteristic among all of them was the lack of piped water, sanitary exhaustion, paving, and no destination of free areas. In other words, the landowner did not need to deliver the allotment with the basic infrastructure already in place, this means that the public authorities would later have to bear all the burden to implement the infrastructure that the population demands.

\subsection{From the 1970s to the mid-1990s}

In the 1970 elections, the elected candidate was Joaquim Barreto Lima, who served his first term for only two years (1971-1972) $)^{5}$. In 1973 he took over the Sobral city hall for his first term, José Parente Prado. In 1974, Sobral registered one of the largest floods on the Acaraú River, and the population living on the banks of the river suffered serious damages, such as the community of Tamarindo, Santa Casa, and Dom Expedito. As a result of the flood and as a resettlement measure, the families received lands in a higher topography site, called Alto Novo (located in the Dom Jose neighborhood). It was in their management that it was also possible to donate land in the northern portion of the city, as a continuation of the already existing Parque Silvana I, which would become, through public initiative, the precarious settlement Alto da Brasília, for the neediest population.

He built in 1976 the Jarbas Passarinho school in the northwest portion, on the axis of expansion in the direction of Meruoca, after the Parque Arizona allotment away from the consolidated area. Aragón (2014) had observed this when said that, at that time, there were no schools where there were students. In this case, what there was next to it was the Parque de Exposições.

From 1977 to 1982, the management is conducted by the elected mayor José Euclides Ferreira Gomes Júnior. His administration became known as modern because, besides starting the construction of the new city hall headquarters, he also implemented the installation of an industrial district, housing developments, and other allotments. Another work that marked the management was the construction of the new market.

During his mandate, one can observe a strong expansion in the north axis. For example, besides the new market, two large allotments of the private initiative were approved, namely Parque Eliodides Pinheiro and Parque Alvorada, in the northern portion toward Serra da Meruoca through Avenida Dr. José Arimatéia.

In 1979, the approval of a Federal Law $-\mathrm{n}^{\circ} 6.766^{6}$ - said that the urban land parceling should be charged by the municipality, at least the green and institutional areas. The city already had many pieces of equipment, as showed in figure 01. In 1980, three subdivisions and a housing complex were approved and implemented in the city of Sobral. In the northern portion in the direction of Massapê, just after Parque Silvana I and II, the Belo Horizonte plateau and the Boa Vista hill were installed, which according to Aragão (2014), it was the first time in the city with all roads paved and obeying the contour lines. The third subdivision was the Parque Joaquim Mariano, near the São Francisco cemetery in Junco, and the construction of the Grajaú housing complex began in the same year.

\footnotetext{
${ }^{4}$ Land generally donated by public authorities, without the minimum basic infrastructure conditions for housing, such as piped water, sewage system, light and road paving.

${ }^{5}$ Due to Institutional Act No. 11 of 14 August 1969, which had the interest of matching the mandates of mayors and governors (BEZERRA, 2008, p. 93).

${ }^{6}$ Urban Land Parcel Law No. 6.766, of December 19, 1979. 
Three private initiative allotments were approved in 1982, namely Nova Betânia in the northeast portion just above Alto da Brasília, Parque Jatobá and Parque São Cristóvão in the southern portion toward Fortaleza, expanding its urban area in this direction, COHAB II housing complex (400 lots) in the southeastern portion of the Sinhá Saboia in the northwestern portion on the left side of the road to Meruoca. Aragão (2014) considers it to be a paradox in the process of expansion and urban structuring of Sobral. The land was donated for the construction of more than 2000 lots to meet the demand for housing, a popular allotment of the public initiative without the necessary basic infrastructure and incompatible with the proposed modernization of space, intended and observed in other areas of the city. This leads one to think of light and opaque spaces, as proposed by Santos (2017). Areas provided with the necessary infrastructure for their fluidity are the light spaces, whereas the opaque spaces are exactly the opposite, that is, territories lacking infrastructure and without the fluidity and investment necessary for their development.

Figure 01 - Urban expansion from 1977 to 1982 (management of José Euclides F. Gomes Jr).

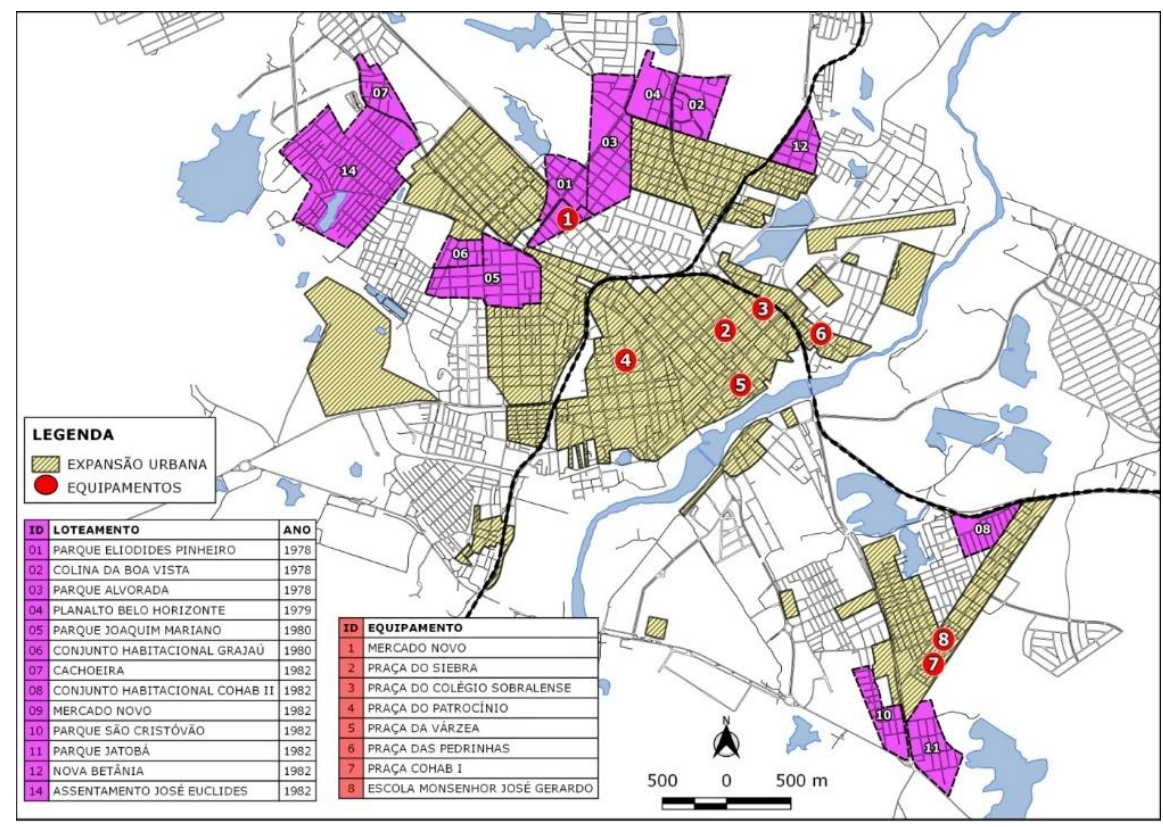

Source: Aragão 2014 / Elaborated by Wellington Galvão Alves (2018).

In 1983, Joaquim Barreto Lima took over as mayor for his second term. One of his first actions was to rebuild the market downtown, due to pressure from traders who did not accept the change of location of the public market, implemented by his predecessor.

During the second administration of Mayor Joaquim Barreto Lima, the private initiative Nova Caiçara allotment had approval in 1983, which according to Aragão (2014), of all the allotments approved until then, it had the greatest impact on Sobral design, both in terms of size and design, which did not respect the importance of the Fazenda Lagoon and the Pajeú Creek as part of the water resources of the Acaraú River basin. They were about to suffer a landing process, disrespecting the previously mentioned Law No. 6.766, which already provided for the protection of water resources.

The management of Joaquim Barreto Lima continues the urban expansion from the private lots and without the obligation to deliver with the necessary infrastructure. One can cite the Nova Colina subdivision in the extreme North in the expansion direction Massapê and Parque das Flores subdivision approved further South, placing two milestones of expansion. It is important to say that for more than 30 years since the homologation, these allotments remain practically uninhabited. One of the factors to imagine, besides the lack of infrastructure, is the distance from downtown, mainly at the time of the homologation. Two other allotments far from the central area are Sítio Cachoeiro and the Planalto Cachoeira, both in the northwestern portion towards Serra da Meruoca at the entrance to the Cachoeiro dam.

Planalto (1984), another allotment next to LASSA, consolidates the Sinhá Saboia Neighborhood as a growing area in the Southern portion. The Havaí Park (1986), in the Junco Neighborhood and side by side to Arizona Park, shows how that sector has received attention since the 1970s. 
With regard to the housing sector, Joaquim Barreto Lima, made the construction of the Ursulita Barreto housing complex feasible in 1983, in the northern portion of the city, connected to the Trajano de Medeiros social center and next to Alto da Expectativa, with 50 single-family housing units.

Because of this, the second management of Joaquim Barreto Lima, according to Aragão (2014), is the first real estate occupation in the history of Sobral, when residents of the risk areas of Alto da Brasília and Expectativa occupied the set as a form of protest against the lack of criteria for the donation of the units. Later, as a way to meet the great demand for housing, the mayor donates a plot of land neighboring Fábrica Coelho, becoming known as the Pantanal do Alto da Brasília, fitting in with the type of precarious settlement. (Figure 02).

Figure 2 - Urban expansion from 1983 to 1988 (management of Joaquim Barreto Lima.)

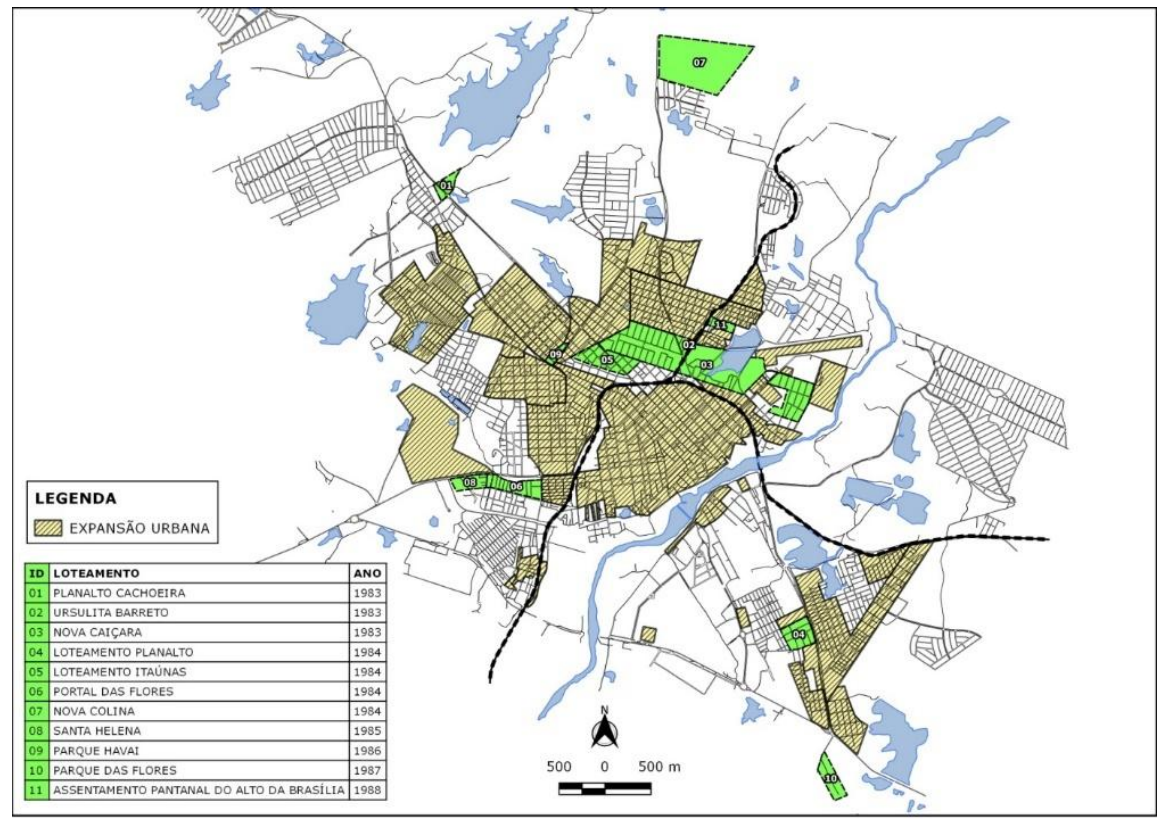

Source: Aragão 2014 / Elaborated by Wellington Galvão Alves / 2018

The 1988 elections were the scene of a historic moment in the political scene of the city of Sobral, with the union of the two historically rival families, Prado and Barreto, who emerged victorious in the elections against the candidates supported by the then state governor, Tasso Jereissati. The candidates José Linhares and his vice-president Cid Ferreira Gomes, with the candidate José Parente Prado victorious in the elections, to take over his second term at the head of Sobral city hall.

With regard to urban structuring, the management did not present any urban development plan, and at that time, the 1988 Federal Constitution was already in force, which in its Chapter II speaks of Urban Policy, set out in Articles 182 and 183, and discusses the role of municipal public authorities in urban planning and development and the social functions of the city with the aim of ensuring the well-being and quality of life of its inhabitants. It was in the management of José Parente Prado that what is now known as the Padre Palhano neighborhood was occupied, from the expropriation of the Arroz farm for the donation of 1,800 lots to the low-income population. It was a settlement of public initiative, but without the minimum infrastructure.

In 1991 and 1992, the urban expansion of Sobral continues along the same lines. In 1991 with the homologation of the Admiro allotment of private initiative, North to Nova Betânia, popularly known as Recanto I. In 1992, three more private initiative subdivisions had approval, namely the Village Betânia, next to the Universidade Estadual Vale do Acaraú (Vale do Acaraú State University, UVA), the Parque Sinhá Saboia subdivision in the central portion of the Sinhá Saboia neighborhood, practically consolidating the neighborhood and uniting the oldest part of the neighborhood with COHABs I and II. The other is in the eastern part, near the cement factory, the Nosso Lar subdivision.

Still, in 1992, the construction of the COHAB III housing complex, in the northern portion of the Cachoeira subdivision, was authorized by the then state governor, Ciro Gomes. 
It was also in 1992 that the occupation process took place in the area between IBAMA forest garden and Terrenos Novos, sheltering approximately 600 families coming, in their great majority, from the flooded areas. There is thus a precarious settlement of community initiative that would later be known as the current Vila União neighborhood.

In the 1992 elections, Francisco Ricardo Barreto Dias was elected, with Aldenor Façanha Júnior as vice-chairman. The administration of Ricardo Barreto went through a strong administrative crisis, reflected in the reliability of his administration, staying only two years ahead of the municipal government, having his mandate revoked in 1994. Even in the face of the administrative crisis, it was possible, before his departure, to authorize by Law Decree no. 005/93 the donation of a 16,000 sq. m. piece of land to the Federal Government, with the objective of building the Centro de Atenção à Criança (Children Attention Center, CAIC), located between the Expectativa and Alto da Brasília neighborhoods.

Through the State Government and the Fundo de Desenvolvimento Industrial (Industrial Development Fund, FDI), there was in 1993 the installation of the footwear industry of the Grendene group and, through the decree of Law No. 055/93, approves the granting of tax incentives in favor of the company, which installation happened on a piece of land ceded by the State, next to the CAIC, representing an appreciation, not only for the neighborhood that housed the industry but also enhanced the attractive capacity of the municipality.

Three other important works took place in Sobral in 1994. According to Aragão (2014), the Colégio Estadual de Referência em Educação, the well-known CIRÃO, Dr. Tomaz Correia Aragão health station, in COHAB I, and Lagoa da Fazenda Park.

These three technical objects, located in different points of the city, helped in the consolidation and resignification of the urban space, occupying the empty lands and giving fluidity to the territory, as they attract different demands (education, health, and leisure).

\subsection{Cid Gomes Management, Participatory Planning and the second Urban Development Master Plan - PDDU 2000}

In the 1996 elections, the elected candidate was Cid Ferreira Gomes, also re-elected in 2000, governing the city for eight consecutive years. This management developed an accelerated process of modernization and restructuring of urban space. The new changes in the territory, resulting from the new systems of objects and actions, ended up converging to the need for new planning, that is, for an achievable urban development.

So, for this to become a reality, it was necessary planning that could be not only well done but also participatory, where the population helped the management to rethink the city, making the reading of reality more assertive and that the return was a better quality of life. At the end of his first mandate, the PDDU of Sobral had approval, the second master plan of the municipality, but the first effective.

The PDDU was decisive in guiding the urban structuring process of the city of Sobral, even before its approval. The city had already gone through significant changes resulting from the policy of urban modernization by the then-mayor Cid Gomes. Among the technical objects that represent the urban structuring process, during the eight years corresponding to the two consecutive periods of its management, one can cite the new central market, popular restaurant, Eclipse Museum, Madi Museum, Arco Boulevard, duplication of the Otthon de Alencar Bridge, José Euclides Ferreira Gomes Bridge, SAMU, Centro de Especialidade Médicas (Medical Specialties Center, CEM), Centro de Especialidade Odontológica (Dental Specialties Center, CEO), municipal library, zoonosis center, city park, Cuba Square, São Francisco Square, convention center, left riverbank park, asphalt plant, Largo das Dores, duplication of avenues, Medical College building, among others.

These interventions in the urban space of Sobral, besides providing a functionalization of the territory, also made it possible to appreciate the space, generating a gravitational field for new developments such as businesses, services, and other businesses. It gave a new characteristic to the urban space of the city, but it is important to say without eliminating the inequalities and contradictions of the territory.

Concerning urban expansion, the perimeter defined in the 2000 PDDU delimits a physical area of $30 \mathrm{~km}^{2}$, quite compact, reaching the point of leaving out of the urban perimeter some allotments previously approved. In 2001, there was a change in the urban perimeter based on Complementary Law No. 13 of October 1, which ended up meeting two demands: the first, to correct the mistake of the perimeter approved in the PDDU that had left out the Planalto Cachoeira allotment (approved in 1983) in the second administration (1983 - 1988) of Mayor Joaquim Barreto Lima, and the second purpose that became clear as the main one, which was the expansion in the direction of the Serra da Meruoca, Morada do Planalto allotment, which is now the 
Renato Parente neighborhood, confirming the continuity and appreciation of this expansion vector as part of municipal planning. Complementary Law, still in the Cid Gomes government, which had the purpose of expanding the urban perimeter, now in the north direction (road to Massapê), was that of No. 20 of December 15, 2003, including in the perimeter the Nova Colina subdivision (homologated in 1984), also of the second management of Joaquim Barreto Lima and including Vila Recanto II, which later, in the government of Leônidas Cristino, would be contemplated with urbanization and popular housing project, becoming Bairro Novo Recanto (Figure 03).

Figure 03 - Urban expansion and pieces of equipmentfrom 1997 to 2004 (management of Cid Gomes)

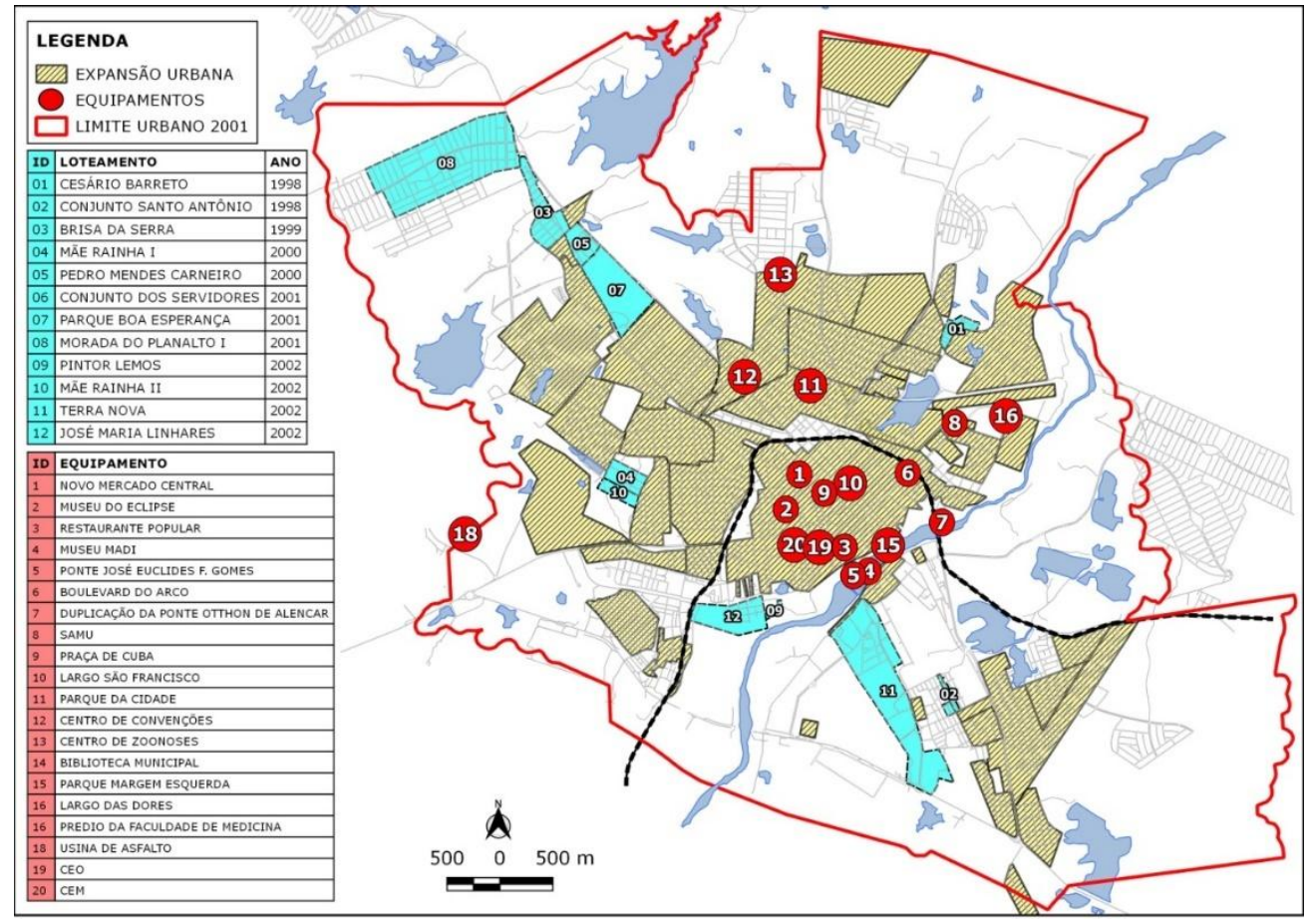

Source: Aragão 2014 / Elaborated by Wellington Galvão Alves (2018).

\subsection{The Plano Diretor Participativoof Sobral (Participatory Master Plan, PDP) 2008}

The PDP of 2008 received approval in the first administration of the mayor Leônidas Cristino and, according to Alves (2011), had its study process for elaboration already in the year 2005, to expand the urban planning also for the Districts, differentiating itself in this first aspect, from the previous plan, which only contemplated the city of Sobral.

The process of participatory construction of the PDP is something that differs from the previous ones by the number of community forums, the number of participants, and the methodology applied. In the process of drafting the PDP, in its purpose of reviewing PDDU, special emphasis was on moments of participation of society, from community forums and included the districts in urban planning, according to Complementary Law No. 028 of 15 December 2008, which brings the delimitation of the urban perimeter of the headquarters of the 16 Districts.

Since the 2008 PDP, the urban expansion of the city of Sobral has intensified, confirming the directions of the already consolidated axes of expansion and giving rise to new axes, reaffirming the economic and political strength and influence of the enterprises and real estate agents in the decisions of the public power and in the direction of the horizontal growth of the city.

Complementary Law No. 33 of December 15, 2010, passed shortly before the resignation of the then-mayor, Leonidas Cristino (in the second year of his second term), regarding the expansion of the urban perimeter, opened paths for the expansion of the urban network on three axes. Two of them consolidated, towards Massapê and Meruoca (this second, extending to the mountain) and the third in the eastern portion, towards the district of Patriarca, along the Marrecas road.

This ended up going against the PDP proposals, which had as reference the guidelines of the city statute, as stated in Article 1 of Complementary Law No. 28 of December 15, 2008. 
This expansion of the urban perimeter in 2010 served to meet the demands of the real estate sector, with the allotments that were approved shortly after, in the management of Mayor Clodoveu de Arruda. For example, in the expansion axis to Serra da Meruoca, the Granville allotment was approved at the limit of the urban perimeter in 2013 (designed to be a controlled access allotment). In the North direction, on the road to Massapê, in 2015 the Conviver allotment was approved (located between a park and the Nova Colina allotment), in addition to another allotment provided for in this expansion axis, on the opposite side of the existing ones. To the East, the expansion ended up giving rise to the Nações neighborhood (called Antônio Carlos Belchior), from two large allotments of the Mãe Rainha group, Moradas da Boa Vizinhança (approved in 2011) and Moradas da Boa Vizinhança II (approved in 2014).

In 2012, the urban perimeter of the city of Sobral underwent another expansion, through Complementary Law No. 35 of June 13, to the west, forming a large urban emptiness, both in the direction of Serra Grande and Serra do Rosário. It has also expanded in the direction of Boqueirão, opening the way for another subdivision of the real estate group Mãe Rainha, approved in the year 2015 (subdivision and condominium Moradas), showing a speculative expansion of allotments deployed in areas bordering the urban perimeter, valuing the empty spaces between them (which usually belong to the same owners), generating a loss to the public power, as it has to bear the costs of expanding infrastructure.

In 2014, the urban perimeter was further increased by Supplementary Law No. 41 of August 11, a law passed by the city council without going through any consultation with the urban planning department of the Sobral city hall, reaching the point of not identifying to which neighborhood the land added to the perimeter would belong, a kind of appendix containing only the information that it would be a Zona de Uso Misto (zone of mixed-use, ZUM).

Figure 04 - Evolution of the urban zone of Sobral.

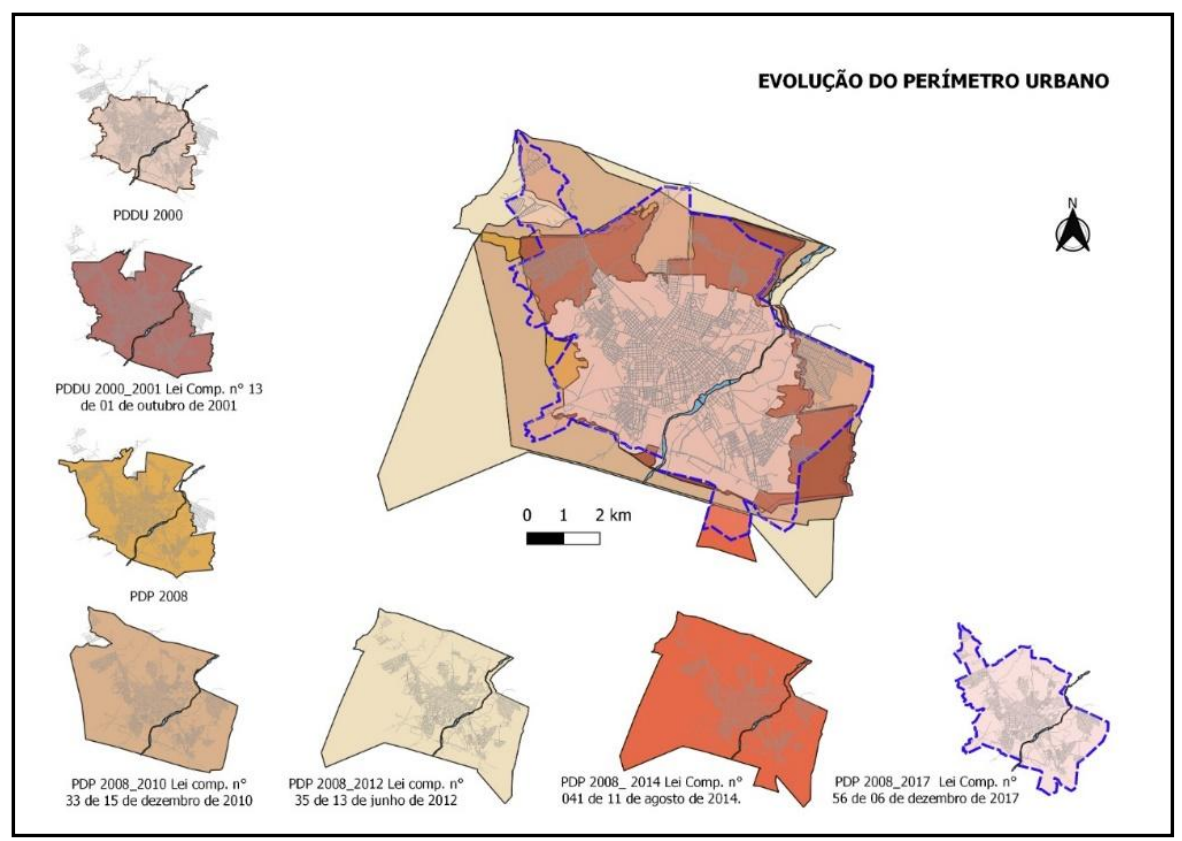

Source: Secretaria de Urbanismo e Meio Ambiente (Environment and urban planning department, SEUMA) Sobral (2019).

\subsection{The reduction of the urban perimeter in the year 2017}

Since the beginning of his administration in 2017, Ivo Gomes has developed studied to prepare a proposal to reduce the urban perimeter of the city of Sobral which, based on the 2000 PDDU area $\left(\mathrm{km}^{2}\right)$, which was $31.30 \mathrm{~km}^{2}$, after six additions, already reached $98.33 \mathrm{~km}^{2}$ in 2014 , an increase of about $200 \%$. When the percentage in areas of the urban spot is analyzed, it reaches $27.65 \mathrm{~km}^{2}$, equivalent to $29 \%$ occupation of the entire perimeter area, leaving $70.68 \mathrm{~km}^{2}$ of urban emptiness or $71 \%$ of unused areas.

It goes against the current concepts of urban planning and development which, among some guidelines, seeks to thicken empty areas, especially in spaces with consolidated infrastructure, aiming at optimization between demands and services and helping to contain, for example, disorderly growth to increasingly distant areas, thus avoiding public 
encumbrance, fragmentation of territory and consequently long displacement, socio-spatial segregation, increased pollution, environmental degradation, and urban emptiness.

So, aiming at a more compact, balanced, inclusive city that encourages mixed-use in the neighborhoods, verticalization and improvement in the quality of life for the population, was the motto to define the criteria for the identification of areas that presented as characteristics: being distant from the urban core, places without basic infrastructure, difficult accessibility of public transport, lack of collective facilities and without population expressiveness (density practically zero).

Three portions of the territory that presented these characteristics were identified, in addition to being outside of any regulated urbanistic project and entered with the project analysis sector of SEUMA of Sobral, as shown in figure 05:

Figure 05 - Areas out of the urbanperimeter in 2014.

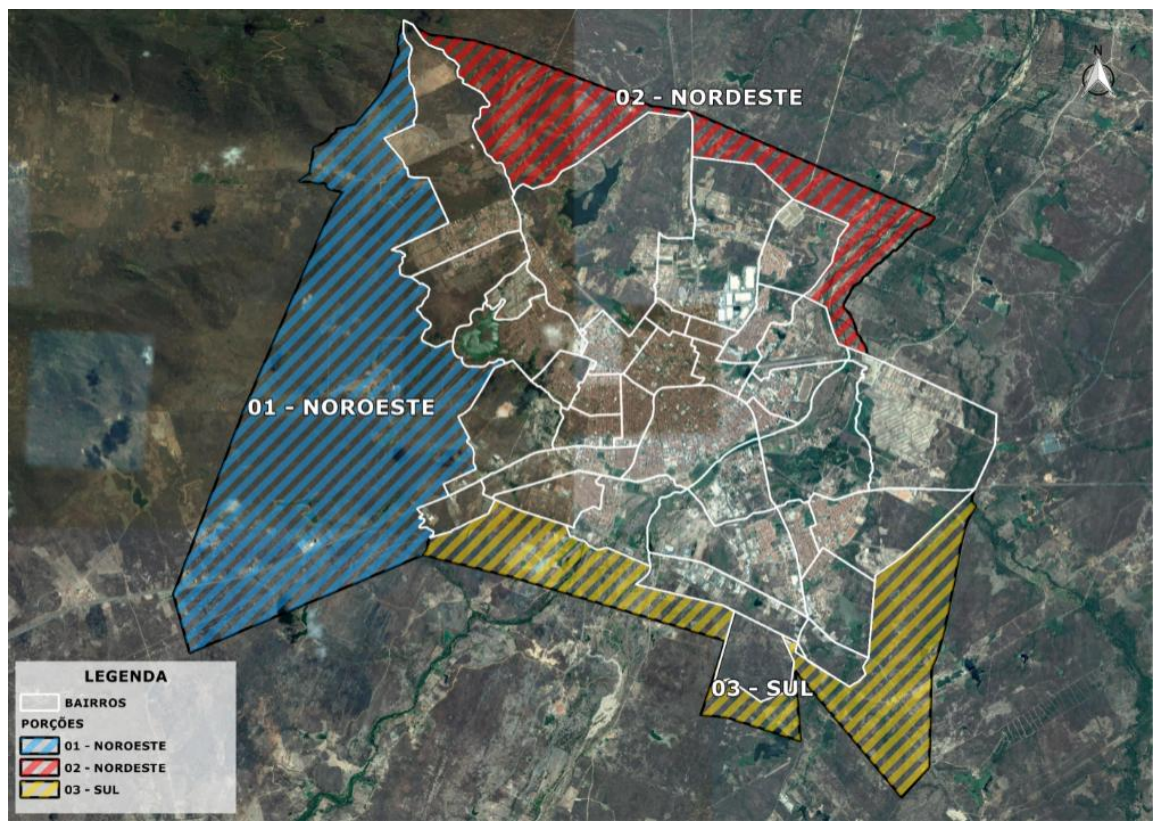

Source: SEUMA, Sobral (2018)

In the northwestern portion (blue), the perimeter moves towards areas on the slope of the Serra da Meruoca, with rugged terrain (slopes and steep slopes), precisely where protection is the guideline, due to environmental fragility. Besides, this large area has very few houses, no public equipment, and the use of the soil is characterized as predominantly rural.

The northeastern portion (red), brings a characteristic of environmental fragility due to the topography (steep slopes next to the Serra da Meruoca) and water resources (Mata Fresca creek and intermittent lagoons in the western portion, and the Acaraú River in the eastern portion of the area). It is an area characterized by strong environmental interest, whose soil use is predominantly agricultural and livestock.

The southern portion (yellow) has low population density with predominantly rural use, and it is where the municipal slaughterhouse is. In other words, it became clear that, in all portions, the very low population density with the absence of infrastructure and the predominant type of activity developed, characterize these areas demarcated as rural.

When removing the three excessive portions of the perimeter, under a new tracing, taking care to consider the physical landmarks (water resources, roads, transmission lines), the coordinates of each vertex (with Datum and official coordinates system - Sirgas 2000, UTM, zone 24 South) and without leaving out the allotments approved, nor the projects with analysis in progress, respecting legal issues, one arrives at a perimeter that is not as thickened, but still with large urban emptiness, and with a clear expansion towards the Serra da Meruoca, showing that the reduction of the perimeter does not compromise the offer of areas for urban expansion, but it helps in the territorial configuration, planning, and supervision of the remaining space. 
The studies for the revision of the new urban zoning of Sobral went together with the proposal of reduction of the urban perimeter and, also, had as support for the foundation of the Plano de Mobilidade Urbana de Sobral (urban mobility plan of Sobral, PLANMOB) and survey on the city, to update the technical register, precisely to revert the fragmented and dispersed form of urbanization in force in the city, aiming to promote efficiency in urban mobility and making it possible, through densification, to stimulate the circulation of cyclists and pedestrians, increasing the movement in the streets, diversifying the modals and improving urban safety, besides encouraging healthier habits. The review also thought about promoting the diversification of uses in the zones, simplifying the zoning, and reducing the spatial cutouts, in addition to enabling and expanding the verticalization, the areas of environmental, and social interest.

\section{Final Considerations}

Due to the lack of norms and guidelines for urban planning, the city of Sobral during the 1970s, 1980s and 1990s expanded through private subdivisions (these almost always without the necessary basic infrastructure and the preservation of institutional areas, green areas and land funds) and precarious settlements of public initiative (also without infrastructure), which helps to understand a little more of the urban and environmental problems still present in the city today. This means that the public power gave conditions for this to happen, helping the private initiative to make its real estate ventures viable (including giving to the allotment owners the power to choose where the city should grow, without much contestation) and without demanding the basics necessary for the implementation of the allotments, due to the lack of municipal legal norms that would give legal power to the public power to impose conditions for expansion, and guidelines and instruments for urban development.

Only in the year 2000, at the end of the first mandate of mayor Cid Gomes, with the approval of the PDDU and the laws that compose it, the municipality had legal mechanisms to guide its development policy and urban structuring, imposing limits and determining different patterns of land use and occupation and thus also having the power of inspection.

The normalization of the territory added to the intention of modernizing the urban space, during the PDDU term, passing through the management of mayors Cid Gomes and Leônidas Cristino, was very important in the structuring and qualification of the several spaces of the city, as it expanded structuring projects, of requalification and public assistance, making the city more beautiful, dynamic and attractive for business and for the population, which gained in quality of life.

With the PDDU review and the approval in 2008 of the PDP, management initially aimed to improve the mechanisms for popular participation in the process of drafting the new plan, in addition to expanding urban planning also to the districts, and this is what happened, including the delimitation of the urban perimeters of the districts. The problem is that, over the years, the PDP has been increased by new complementary laws that ended up expanding the urban perimeter of the city of Sobral too much (with the creation of new neighborhoods in areas with practically no density or immediate demand), contributing negatively to dispersed and fragmented urbanization, bringing as a consequence the burden on public accounts with the implementation of underutilized infrastructure and increasing real estate speculation.

In 2017, already under the management of the current mayor Ivo Gomes, as a way to stop these urban expansions and plan a more compact city, aiming to occupy the urban empty zones in the areas with implemented infrastructure, provide greater diversity of uses and better construction parameters for the neighborhoods of Sobral, the reduction of the urban perimeter was approved first and in the following year (2018), the new urban zone. The scenario projected for 2020, in the process of revising the new master plan, is of a more prepared city, with the experience of having already passed through three master plans, with participatory and efficient planning, public policies, and instruments for urban development and territorial planning.

\section{References}

ALVES, Maria do Carmo. Planejamento Urbano e Formação Territorial: Sobral e suas contradições. Campinas: Edições Territorial, 2011.

ARAGÃO, Francisco Edilson Ponte. A estruturação urbana de Sobral na segunda metade do século XX: a cidade para além do arco formado pelo rio e a ferrovia / Francisco Edilson Ponte Aragão - Dissertação (Mestrado em Arquitetura e Urbanismo) - Universidade Presbiteriana Mackenzie, São Paulo, 2014.

ARAÚJO, F. Sadoc de. Raízes portuguesas do Vale do Acaraú. 2a ed. - Sobral: Edições UVA. 2000.

BRASIL. Constituição (1988). Constituição da República Federativa do Brasil. Disponível em: <http://www.planalto.gov.br/ccivil 03/constituicao/constituicao compilado.htm>. Acesso em: 13 de fev. 2018. 
Lei n ${ }^{\circ}$ 10.257, de 10 de julho de 2001. Estatuto da Cidade e Legislação Correlata. - 2. ed., atual. - Brasília: Senado Federal, Subsecretaria de Edições Técnicas, 2002.

HOLANDA, Virgínia Célia Cavalcante de; LIMA, Juscelino Gomes. "Vende-se" uma cidade no sertão cearense: Vetores e condições para transformações espaciais em Sobral/CE.In Revista da Casa da Geografia de Sobral (RCGS), Sobral - CE, V.16, n. 1, p.40-56, 2014.

PINHEIRO, Otilie Macedo. Plano diretor e gestão urbana. 3.ed. ver. atual. Florianópolis: Departamento de Ciências da Administração / UFSC; (Brasília): CAPES: UAB, 2014.

ROCHA, Herbert de Vasconcelos. O lado Esquerdo do Rio. São Paulo: Hucitec: Secretaria de Desenvolvimento da Cultura e do Turismo, Sobral: Escola de Formação em Saúde da Família Visconde de Sabóia, 2003.

ROCHA, Herbert de Vasconcelos. Contribuição para o Estudo do Desenho Urbano de Sobral: Século XIX. Dissertação (mestrado): Universidade Federal do Ceará, Centro de Tecnologia. Programa de Pós-Graduação em Arquitetura e Urbanismo e Design, Fortaleza, 2017.

SANTOS, Milton. Espaço e Método. 5.ed. 2. reimpr - São Paulo: Editora da Universidade de São Paulo, 2014.

SANTOS, Milton. Metamorfoses do Espaço Habitado: Fundamentos Teóricos e Metodológicos da Geografia. Em colaboração com Denise Elias. 6.ed. 2. reimpr - São Paulo: Editora da Universidade de São Paulo, 2014.

SANTOS, Milton. A Natureza do Espaço: Técnica e Tempo, Razão e Emoção. 4.ed. 2. reimpr - São Paulo: Editora da Universidade de São Paulo, 2017. 